\title{
Historical Perspective of Regeneration in Spinal Cord Injury (SCI)
}

Faiza Ahmed*, Vamsi Garimella ${ }^{8}$, Uzoamaka Nwokorie ${ }^{1}$, Adnan Choudhry ${ }^{4}$, Godsgift Enebong Nya ${ }^{1,6}$, Andre Thompson $^{2}$, Gertrude 0 Bassey ${ }^{3}$, Fernand Jean- Baptiste ${ }^{1}$, Shanthi Potla ${ }^{5}$, Rujina Munim ${ }^{7}$ and Timothy Fernandez ${ }^{9}$

${ }^{1}$ Doctor of Medicine Graduate, University of Science, Arts and Technology, Montserrat

${ }^{2}$ Doctor of Medicine Graduate, Washington University of Health and Science, Belize

${ }^{3}$ Department of Family Medicine, Bon Secours Medical Group, USA

${ }^{4}$ Department of Medical Education, Neuroscience Research \& Medical Education Program, Canada

${ }^{5}$ Medical Student, Avalon University School of Medicine, Curacao

${ }^{6}$ John Hopkins Hospital, USA

${ }^{7}$ Visitor Consultant, Bentley University, USA

${ }^{8}$ Medical Student, Howard University College of Medicine, USA

${ }^{9}$ Resident Physician Internal Medicine, Emory University School of Medicine, USA

Submission: June 09, 2020; Published: June 30, 2020

*Corresponding author: Faiza Ahmed, MD Program, Avalon University School of Medicine, Curacao

\begin{abstract}
Spinal cord restoration has inspired thoughtful discussions and gleaned keen insights from the scientific and clinical community at large. Due to the nature of the health complications which are associated with spinal cord injury, spinal cord restoration holds promising potential in significantly improving the quality of life of spinal cord injury sufferers, especially for those who are young. Research has shown that the nerves found in the Peripheral Nervous System (PNS), exclusively those in the exterior side of the brain and in the spinal cord are capable of regeneration. When these PNS cells were embedded in the damaged spinal cord, it improved restructuring the tissue. However, since spinal cord trauma has become a worldwide problem, several specialists and researchers have put a lot of effort into finding solutions. Axonal restoration, electric invigoration, Netrins, and stem cells among other areas have become fields of focus. Therefore, this research work is aimed at determining insightful abilities on how to regenerate the human motor neurons more so in scientific laboratories. Hence, it would provide robust platforms for the discovery of therapeutic objectives and drug verification.
\end{abstract}

Keywords: Spinal injury; Regenerating the spine; Stem cells; Spine repair; Spinal cord injury (SCI); Spine therapy

\section{Introduction}

Injuries of the spinal cord have been reported for many decades. Analysis of American Egyptologist, Edwin Smith, papyrus records reveals that even during ancient times, society acknowledged spinal cord injury as a dangerous health condition and a menace that could not be treated [1]. Indeed, tremendous efforts undertaken by physicians amongst ancient societies have been recorded. However, their effort never yielded any fruitful outcomes as they too believed that such high caliber injuries could not be managed and that if one loses their spinal cord function to any form of injury, the nerve fibers would not operate optimally. Therefore, they believed that the condition would be synonymous with spinal cord failure [2]. In the modern age, scientists are actively exploring novel therapeutic strategies in order to control or even reverse the adverse effects of spinal cord injury. Although this concerted effort may appear to be in its infancy, many scientists such as Theodor Schwann and Santiago Ramon Cajal in the 1830s as well as in the 1890s discovered that the problem which was generally deemed untreatable was indeed curable [3]. In his research, Santiago discovered that there was a possibility of damaged nerve cells, especially those that comprised the peripheral nervous system, to regrow physiologically in mammals [4].These revelations were later reinforced in the early 
1990s by the renowned scientist J.F. Tello, who revealed that an injured spinal cord could regenerate but would require constant nourishment. Nevertheless, this research did not pick up until after the Second World War when the discovery of sophisticated antibiotics and enhanced surgical techniques were developed [5].

Upon discovering that spinal cord nerves were capable of rejuvenation, many scientists then steered their research towards understanding how such nerves could be nourished [6]. Led by Rita Levi-Montalcini and Viktor Hamburger, this team of medical practitioners in the 1960 s conducted research with the sole aim of discovering what elements made nourishment possible in nerve cells. During their research, they discovered that there was a Nerve Growth Factor (NGF) which made it possible for the damaged nerve cells to regrow. The discovery of NGF preceded that of Brain-Derived Neurotrophic Factor (BDNF) which was put forward by Yves Barde. These scientists also discovered that the growth factors received different responses from different cells. According to these scholars, the main aim of the research was to ensure that they cure the patients and enable them to regain their full operation [7]. Spinal cord injury represents an epidemic which affects millions of people across the world in both developed and developing countries. Current estimates suggest that more than 130,000 people around the world suffer from spinal cord related trauma. Unfortunately, a significant proportion of spinal cord injury sufferers are young and fall under the age of 19 [8]. According to a report released by the International Campaign for Cures of Spinal Cord Injury Paralysis Online (ICCSCIP), spinal cord injury is associated with a bevy of health complications including disability in the form of wheelchair assistance. The effects were evident, stretching from economic aspects to social destabilization. As witnessed in the United States of America, both long term costs and those associated with the social wellbeing of such patients increased drastically, culminating in a staggering $\$ 7.7$ billion. The situation was found to be similar in Canada and Britain [9].

\section{Discussion}

\section{Advances in Research}

Based on the immense socio-economic burden wrought by the spinal cord injury epidemic, it was evident that there was a need to conduct more research by the various agencies [10]. This outcome prompted many rigorous studies to be carried out by several medical institutions, individual researchers, and medical practitioners. However, unless thoughtful work and effort are devoted to this issue, such research may still prove unhelpful towards eliminating the problem [11]. It should be noted that some effects of spinal cord injury such as loss of sexual functionality, bladder and bowel infections, loss of breathing capacity, inability to ambulate and cognitive impairment are very serious to the overall well-being of any person [12]. This underscores the importance of focused research that is primarily scoped to discovering viable therapeutic options for patients with spinal cord injuries in order to alleviate their physical disease burden. As illustrated, these new research findings are directed towards discovering the viable therapeutic options for spinal cord problems. Different scientists focused on distinctive areas of concern in an attempt at converging a specific set of conclusions. One of the significant areas where recent research has focused on is axon growth. In early 1988, a renowned physician, Martin Schwab put forward two key factors that hindered the growth of the wounded mammalian spinal cord [13]. Since then, his findings have been buttressed by other discoveries, such as in 2009 , where the regeneration of any mammalian spinal cord was found to be triggered by anti-Nogo-A, an antibody that promotes neuronal reorganization and character advancement [14]. During his research, Martin Schwab conducted murine studies in which he observed that after administering the antibody, there was a steady growth [15]. Also, he realized that after using both the antibody IN-1 and the earlier nourishment booster NT-3, there was a vast, unexpected regrowth of the damaged rat nerves [16].

Researchers also observed that amongst the injured spinal cord nerve cells, there was a minor rate of necrosis [17]. This led them to conclude that antibodies not only promoted the regrowth of damaged nerve cells, but also prevented necrosis $[17,18]$ These factors included the NT-3 which is a Neurotrophin, BDNF (brainderived neurotrophic factor), FGF (Fibroblast Growth Factor) and NGF $[16,19]$. Following these discoveries, Dr. Ida Black and his coworkers achieved a significant milestone in 2000, when they successfully attempted to make transplantation possible and used it to treat some of the neurological infections. Using NT-3 and BDNF, they were able to prove that such a treatment was possible; hence triggering research extensions in the field $[16,19,20]$. Apart from the axon being the primary aspect investigated by many researchers, scientists have also shifted concern to investigate how such damaged nerves can grow beyond the injury site to reconnect with other parts of the nerve. Dr. Mark Tessier-Lavigne, for instance, established that proteins such as netrins are essential in rejoining the damaged nerve to the central nervous system [21,22]. In addition, scientists from the Centre for Paralysis Research at the University of Purdue came up with validation points on the use of Polyethylene Glycol (PEG) in guinea pigs to facilitate the immediate restoration of nerve functionality, especially at the membrane [23]. During this process, the team realized that the fibroblast, which is the cell outside the skin covering the spinal cord, helped to produce neurotrophin-3, which facilitates the proper healing of damaged nerves. According to Dr. Marion Murray from the University of MCP Hahnemann, this was the reason why rats that were used as test subjects due to their ability to regenerate faster $[21,24]$. However, apart from the use of proteins, the research team from Purdue University also concluded that electrical invigoration could be used as one of the methods for nerve rejoining [25]. During their study, they planted a tiny battery pack around a small dog, and after some days, they realized that the dog's damaged nerve had rejoined [26]. Despite the heavy work done on the axon and protein front, 
researchers have developed interests in many potential targetareas for cure of the spinal cord. In recent years, some of the emerging areas include neuroprotection, which focused mainly on methylprednisolone, glutamate (AMPA) Receptor Blockers, and 4-Aminopyridine, among others [27]. These are the clinical aspects that were also aligned towards improving the time taken for the healing processes of the damaged tissues [28]. Even though the methodologies were proven to be effective, it was recommended that further research was required before such drugs could be administered to human beings as all the tests were carried out using animals. To be precise, its effectiveness on human anatomy was not validated [29].

\section{Role of Stem Cells}

In 1994, Fred Gage made a significant discovery. He proposed that the human skin cells could produce growth factors and neurotransmitters, which subsequently trigger spinal cord sensory cells which in turn stimulate regeneration [30]. This hypothesis developed by Fred Gage was re-emphasized by Lars Olson from the Institute of Karolinska. Together, they supported this hypothesis with observations made from studies conducted on rats. However, they recommended that such results would be realistic if conducted with a larger sample [31]. From the research analysis, it is clear that most researchers were only focused on why spinal cord regeneration was impossible. The researchers failed to investigate the aspect from a broader perspective. To be precise, they failed to establish and evaluate the core reasons that triggered the difficulties in rejoining the nerves after injuries [32]. This was what prompted the 2000 research which revealed that in any damaged tissue, there is more protein fibrinogen which in most cases prevents clotting, thus hindering proper healing $[33,34]$. This unique finding led to the use of enzymes in the treatment of such illness. This discovery is regarded as one of the significant breakthroughs in the rehabilitation of human health but requires further testing [35].

\section{Conclusion}

Even though many studies are still on-going, the notion that spinal cord illnesses are incurable is no longer accurate (refer to Figure 1). Figure 1 lists all the cell types that are utilized as therapy for SCI patients with references associated with each variety of cells. To sum up, cellular therapies in combination with different regeneration approaches are the new promising solution to SCI problems. In the past, most spinal cord injuries were permanent and negatively impacted upon their individual personal development through financial and social constraints [36-45]. This revolutionary discovery paves path forward to restore function in SCI patients after traumatic injury. Therefore, people are advised that even if there has been tremendous progress in the development of curative measures for the spinal cord epidemic, there is a pressing need for therapy to prevent the deleterious sequelae of spinal cord injury and other associated negative health outcomes [37,46-56].

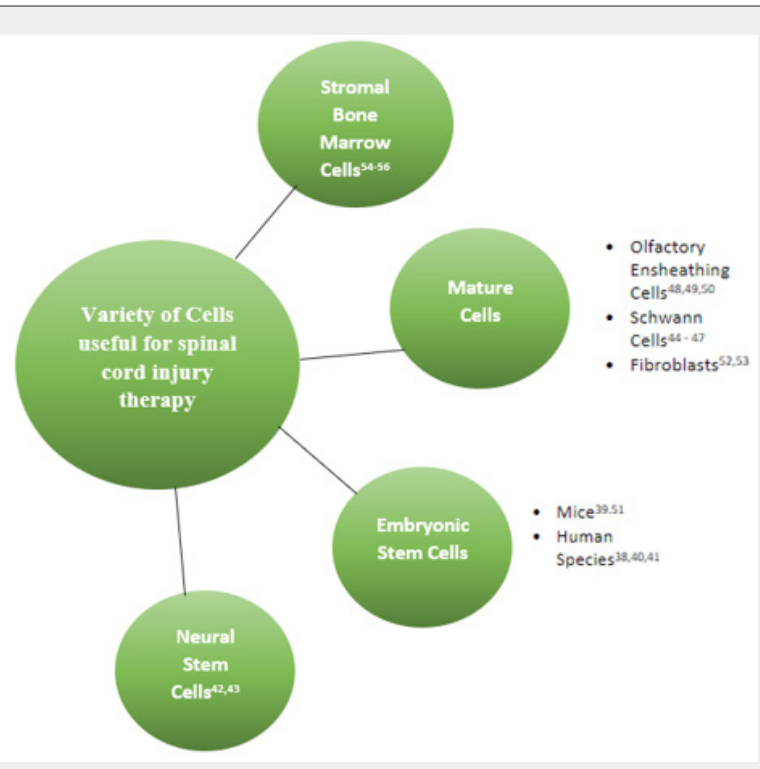

Figure 1: Different types of cells that are useful as therapy in SCI patients.

\section{References}

1. Allen JP, Mininberg DT (2005) The art of medicine in ancient Egypt. New York: Metropolitan Museum of Art.

2. Luba Vikhanski (2001) Thinking the Unthinkable About Spinal Cord
Regeneration. In Search of the Lost Cord: Solving the Mystery of Spinal Cord Regeneration. Washington: Joseph Henry Press.

3. Hannila SS, Filbin MT (2008) The role of cyclic AMP signaling in promoting axonal regeneration after spinal cord injury. Exp Neurol 209(2): 321-332. 


\section{Open Access Journal of Neurology \& Neurosurgery}

4. Nicholls J, Saunders N (1996) Regeneration of immature mammalian spinal cord after injury. Trends neurosci 19(6): 229-234.

5. Fouad K, Schnell L, Bunge MB, Schwab ME, Liebscher T, et al. (2005) Combining Schwann cell bridges and olfactory-ensheathing glia grafts with chondroitinase promotes locomotor recovery after complete transection of the spinal cord. Journal of Neuroscience 25(5): 11691178 .

6. Bradbury EJ, Mc Mahon SB (2006) Spinal cord repair strategies: why do they work? Nat Rev Neurosci 7(8): 644-653.

7. Rauskolb S, Zagrebelsky M, Dreznjak A, Deogracias R, Matsumoto T, et al. (2010) Global Deprivation of Brain-Derived Neurotrophic Factor in the CNS Reveals an Area-Specific Requirement for Dendritic Growth. Neurosci 30(5): 1739-1749.

8. (2009) National Spinal Cord Injury Association. Report on injuries in the United States. Washington: NSCIA.

9. Sipski ML, Alexander CJ, Rosen R (2001) Sexual arousal and orgasm in women: effects of spinal cord injury. Ann Neurol 49(1): 35-44.

10. Bang MS, Lim SH (2006) Paraplegia caused by spinal infection after acupuncture. Spinal Cord 44(4): 258-259.

11. Maier IC, Ichiyama RM, Courtine G, Lisa Schnell, Igor Lavrov, et al. (2009) Differential effects of anti-Nogo-A-antibody treatment and treadmill training in rats with incomplete spinal cord injury. Brain 132(6): 1426-1440

12. Schnell L, Schwab ME (1990) Axonal regeneration in the rat spinal cord produced by an antibody against myelin-associated neurite growth inhibitors. Nature 343(6255): 269-272.

13. Schwab ME, Bartholdi D (1996) Degeneration and regeneration of axons in the lesioned spinal cord. Physiol Rev 76(2): 319-370.

14. Raineteau O, Fouad K, Noth P, Thallmar M, Schwab ME (2001) Functional switch between motor tracts in the presence of the $\mathrm{mAb}$ IN-1 in the adult rat. Proc National Academy Science USA 98(n): 69296934.

15. Maisonpierre PC, Le Beau MM, Espinosa R $3^{\text {rd }}$, Nancy Y Ip, Leonardo Belluscio, et al. (1991) Human and rat brain-derived neurotrophic factor and neurotrophin3: gene structures, distributions, and chromosomal localizations. Genomics 10(3): 558-568.

16. Woodbury D, Schwarz EJ, Prockop DJ, Black IB (2000) Adult rat and human bone marrow stromal cells differentiate into neurons. Neurosci Res 61(4): 364-370.

17. Sun W, Sun C, Lin H, Zhao H, Wang J, et al. (2009) The effect of collagenbinding NGF-beta on the promotion of sciatic nerve regeneration in a rat sciatic nerve crush injury model. Biomaterials 30(27): 4649-4656.

18. Tuszynski M, Blesch A (2004) Nerve growth factor: from animal models of cholinergic neuronal degeneration to gene therapy in Alzheimer's disease. Prog Brain Res 146: 441-449.

19. Marcos S, Backer S, Causeret F, Tessier-Lavigne M, Bloch Gallengo E (2009) Differential roles of Netrin-1 and its receptor DCC in inferior olivary neuron migration. Mol Cell Neurosci 41: 429-439.

20. Borgens RB, Shi RY (2000) Immediate recovery from spinal cord injury through the molecular repair of nerve membranes with polyethylene glycol. FASEB J14(1): 27-35.

21. AJ Aguayo, S David, GM Bray (1981) Influences of the glial environment on the elongation of axons after injury: Transplantation studies in adult rodents. J Exp Biol 95: 231-240.

22. Miya D, Tessler A, Giszter S, Mori F, Murray M (1997) Fetal transplants alter the development of function after spinal cord transection in newborn rats. J Neurosci 17(12): 4856-4872.
23. Borgens R, Toombs J, Breur G, et al. (1999) An imposed oscillating electrical field improves the recovery of function in neurologically complete paraplegic dogs. J Neurotrauma 16(7): 639-657.

24. Sisken BF, Walker J, Orgel M (1993) Prospects on clinical applications of electrical stimulation for nerve regeneration. Journal of cellular biochemistry 51(4): 404-409.

25. Bracken MB, Shephard MJ, Holford TR, L Leo-Summers, E F Aldrich, et al. (1997) Methylprednisolone or trilazad mesylate administration after acute spinal cord injury: 1-year follow up. Results of the third National Acute Spinal Cord Injury randomized controlled trial. Neurosurg 89(5): 1597-604.

26. Brewer KL, Bethea JR, Yeziers RP (1999) Neuroprotective Effects of Interleukin-10 Following Excitotoxic Spinal Cord Injury. Experimental Neurology 159(2): 484-493.

27. DeForge D, Nymark J, Lemaire E, S Gardner, M Hunt, et al. (2004) Effect of 4aminopyridine on gait in ambulatory spinal cord injuries: a doubleblind, placebo-controlled, crossover trial. Spinal Cord 42(12): 674-685

28. Tuszynski MH, Senut MC, Ray J, Roberts J, UH S Gage FH (1994) Somatic gene transfer to the adult primate CNS: In vitro and In vivo characterization of cells genetically modified to secrete nerve growth factor. Neurobiol Dis 1(1-2): 67-78.

29. Lazo-Gómez R, Tapia R (2016) Motor Alterations Induced by Chronic 4-Aminopyridine Infusion in the Spinal Cord In vivo: Role of Glutamate and GABA Receptors. Frontiers in Neuroscience 10: 200.

30. Adams RA, Bauer J, Flick MJ, Sikorski SL, Nuriel T, et al. (2002) The fibrin-derived $\gamma$ 377-395 peptide inhibits microglia activation and suppresses relapsing paralysis in central nervous system autoimmune disease. The Journal of Experimental Medicine 204(3): 571-582.

31. McDonald JW, Sadowsky C (2002) Spinal-cord injury. The Lancet 359(9304): 417-425.

32. Houle JD, Tom VJ, Mayes D, Wagoner G, Phillips N, et al. (2006) Combining an autologous peripheral nervous system bridge and matrix modification by chondroitinase allows robust, functional regeneration beyond a hemi section lesion of the adult rat spinal cord. J Neurosci 26(28): 7405-7415.

33. DJ Barakat, SM Gaglani, SR Neravetla, AR Sanchez, CM Andrade, et al. (2005) Survival integration, and axon growth support of glia transplanted into the chronically contused spinal cord. Cell Transplant 14(4): 225-240.

34. Park DH, Eve DJ, Sanberg PR, Musso J, Bachstetter AD, et al. (2010). Increased Neuronal Proliferation in the Dentate Gyrus of Aged Rats Following Neural Stem Cell Implantation. Stem Cells and Development 19(2): 175-180

35. Sang Ryong Jeon, Hyung Il Seo, Joong Kee Min, Seong Who Kim (2010) Therapeutic effects of Wnt secreting fibroblast implantation in spinal cord injury of rat. Proceedings of $2^{\text {nd }}$ international Congress of Asia Oceania Neurotrauma Society.

36. Young W (2014) Spinal Cord Regeneration. Cell Transplantation 23(45): 573-611.

37. Adams M, Cavanagh JFR (2004) International Campaign for Cures of Spinal Cord Injury Paralysis (ICCP): another step forward for spinal cord injury research. Spinal Cord 42(5): 273-280.

38. Bain G, Kitchens D, Yao M, Huettner JE, Gottlieb DI Embryonic stem cells express neuronal properties in vitro. Developmental biology 168 : 342-57.

39. Stephanie M Willerth, Tracy E Faxel, David I Gottlieb, Shelly E Sakiyama-Elbert (2007) The Effects of Soluble Growth Factors on Embryonic Stem Cell Differentiation Inside of Fibrin Scaffolds. Stem Cells 25(9):2235-2244. 
40. Levenberg S, Burdick JA, Kraehenbuehl T, Langer R (2005) Neurotrophin-induced differentiation of human embryonic stem cells on three-dimensional polymeric scaffolds. Tissue Eng11(3-4): 506512

41. Levenberg S, Huang NF, Lavik E, Rogers AB, Itskovitz-Eldor J, et al (2003) Differentiation of human embryonic stem cells on threedimensional polymer scaffolds. Proc Natl Acad Sci USA 100(22): 12741-12746.

42. Teng YD, Lavik EB, Qu X, Park KI, Ourednik J, et al. (2002) Functional recovery following traumatic spinal cord injury mediated by a unique polymer scaffold seeded with neural stem cells. Proc Natl Acad Sci USA 99(5): 3024-3029.

43. Mahoney MJ, Anseth KS (2006) Three-dimensional growth and function of neural tissue in degradable polyethylene glycol hydrogels. Biomaterials 27(10): 2265-2274.

44. Blakemore WF (1997) Remyelination of CNS axons by Schwann cells transplanted from the sciatic nerve. Nature 266(5597): 68-69.

45. David S, Aguayo AJ (1981) Axonal elongation into peripheral nervous system "bridges" after central nervous system injury in adult rats. Science 214(4523): 931-933.

46. Xu XM, Guenard V, Kleitman N, Aebischer P, Bunge MB (1995 A combination of BDNF and NT-3 promotes supraspinal axonal regeneration into Schwann cell grafts in adult rat thoracic spinal cord. Exp Neurol 134(2): 261-272.

47. Xu XM, Chen A, Guenard V, Kleitman N, Bunge MB (1997) Bridging Schwann cell transplants promote axonal regeneration from both the rostral and caudal stumps of transected adult rat spinal cord. J neurocytol 26(1): 1-16.

48. Ruitenberg MJ, Vukovic J, Sarich J, Busfield SJ, Plant GW (2006) Olfactory ensheathing cells: characteristics, genetic engineering, and therapeutic potential. J Neurotrauma 23(3-4): 468-478.
49. Li Y, Field PM, Raisman G (2000) Repair of adult rat corticospinal tract by transplants of olfactory ensheathing cells. Science 277 (5334): 2000-2002.

50. Li Y, Field PM, Raisman G (1988) Regeneration of adult rat corticospinal axons induced by transplanted olfactory ensheathing cells. J Neurosci 18(24): 10514-10524.

51. Chen J, Bernreuther C, Dihne M, Schachner M (2005) Cell adhesion molecule 11-transfected embryonic stem cells with enhanced survival support regrowth of corticospinal tract axons in mice after spinal cord injury. J Neurotrauma 22(8): 896-906.

52. Blesch A, Tuszynski MH (2003) Cellular GDNF delivery promotes growth of motor and dorsal column sensory axons after partial and complete spinal cord transections and induces remyelination. The Journal of comparative neurology 467(3): 403-417.

53. Tuszynski MH, Grill R, Jones LL, McKay HM, Blesch A (2002) Spontaneous and augmented growth of axons in the primate spinal cord: effects of local injury and nerve growth factor-secreting cell grafts. J Comp Neurol 449(1): 88-101.

54. Ohta M, Suzuki Y, Noda T, Ejiri Y, Dezawa M, et al. Bone marrow stromal cells infused into the cerebrospinal fluid promote functional recovery of the injured rat spinal cord with reduced cavity formation. Exp Neurol 187(2): 266-278.

55. Wu S, Suzuki Y, Ejiri Y, Noda T, Bai H, et al. (2003) Bone marrow stromal cells enhance differentiation of cocultured neurosphere cells and promote regeneration of injured spinal cord. J Neurosci Res 72(3): 343-351.

56. Bakshi A, Barshinger AL, Swanger SA, Madhavani V, Shumsky JS, et al. (2006) Lumbar puncture delivery of bone marrow stromal cells in spinal cord contusion: a novel method for minimally invasive cell transplantation. J Neurotrauma 23(1): 55-65.

\section{Your next submission with Juniper Publishers} will reach you the below assets

- Quality Editorial service

- Swift Peer Review

- Reprints availability

- E-prints Service

- Manuscript Podcast for convenient understanding

- Global attainment for your research

- Manuscript accessibility in different formats

( Pdf, E-pub, Full Text, Audio)

- Unceasing customer service

Track the below URL for one-step submission

https://juniperpublishers.com/online-submission.php 